\title{
ANTISEPTIC AND ANTIBIOTIC RESISTANCE IN GRAM-NEGATIVE BACTERIA CAUSING URINARY TRACT INFECTION IN SPINAL CORD INJURED PATIENTS
}

\author{
By David J. Stickler, ${ }^{1}$ B.Sc., M.A., D.Phil., Brian Thomas, ${ }^{1}$ B.Sc., Ph.D. and \\ Jagdish C. Chawla, ${ }^{2}$ M.B., B.S., F.R.C.S., M.D., A.M. \\ ${ }^{1}$ Department of Applied Biology, University of Wales Institute of Science E Technology, \\ Cardiff; ${ }^{2}$ Welsh Spinal Unit, Rookwood Hospital, Cardiff, U.K.
}

\begin{abstract}
Fifty-seven isolates of Gram-negative bacterial species from urinary tract infections in spinal cord injured patients were tested for their sensitivity to chlorhexidine, cetrimide, glutaraldehyde, phenyl mercuric nitrate (PMN), a phenolic disinfectant (Hycolin) and a proprietary antiseptic containing a mixture of picloxydine, octylphenoxypolyethoxyethanol and benzalkonium chloride (Resiguard). None of the isolates were resistant to glutaraldehyde, Hycolin or PMN but a substantial percentage were resistant to chlorhexidine (44 per cent), cetrimide ( 26 per cent) and Resiguard ( 42 per cent). -The resistant organisms were members of the genera Proteus, Providencia and Pseudomonas and they were also generally resistant to five, six or seven antibiotics. Significant correlations were observed between multiplicity of antibiotic resistance and the minimum inhibitory concentrations of the three cationic antiseptics. It is suggested that an antiseptic policy for the bladder management of spinal cord injured patients that relies on the extensive use of cationic agents might lead to the selection of a flora of notoriously drug-resistant species.
\end{abstract}

Key words: Gram-negative urinary bacterial sensitivity; Cationic agents; Drug resistance.

\section{Introduction}

DURING the course of studies on the mode of development of urinary tract infection in intermittently catheterised male paraplegic patients (Stickler, Wilmot \& O'Flynn, I971; O'Flynn and Stickler, I972), it was observed that strains of Proteus mirabilis, Pseudomonas aeruginosa, Providencia stuartii and Klebsiella (colonising the urethral meatus), could survive washing with aqueous chlorhexidine $(600 \mu \mathrm{g} / \mathrm{ml})$, which was performed prior to the insertion of the catheter. Laboratory tests subsequently showed that many of these bacteria had minimum inhibitory concentrations (MICs) of chlorhexidine of up to $800 \mu \mathrm{g} / \mathrm{ml}$ (Stickler, 1974; Stickler \& Thomas, I976), well in excess of the $10-50 \mu \mathrm{g} / \mathrm{ml}$ originally reported to inhibit the growth of these Gram-negative species (Davies, et al., I954). These chlorhexidine resistant strains were, of course, isolated from a site at which they had been repeatedly exposed to the antiseptic and it is perhaps understandable that the application of such a strong environmental pressure should lead to the selection of these resistant strains. In order to ascertain whether resistance to the antiseptics is a more general phenomenon, or is limited to such special circumstances, Stickler \& Thomas (I980) made a collection from general practice, antenatal clinics and local hospitals, of 802 isolates of Gram-negative bacteria causing urinary tract infection. The sensitivity U.K.

${ }^{2}$ Requests of reprints to Jagdish D. Chawla, Rookwood Hospital, Cardiff, CF2 5 YN. 
of this collection to six antiseptics and eight antibiotics was recorded. In this paper we wish to report the sensitivities of those organisms that were isolated from the spinal injured patients at Rockwood Hospital and present an analysis of the data that was not undertaken in the study of Stickler \& Thomas (1980).

\section{Bacteria}

\section{Methods and Materials}

The bacteria used in this study all originated from cases of significant bacilluria. They were collected over a I2-month period. Repeated isolates of the same species from individual patients were excluded from the survey. The bacteria were identified using the methods of Cowan \& Steel (1974) and in some instances with the API 20E Microtube System (API Products Ltd.). Escherichia coli NCTC I04I 8 and Pr. mirabilis 6I (Stickler, I974) were used as control organisms in the sensitivity testing.

\section{Antibacterial Agents}

The chlorhexidine digluconate and cetrimide were obtained from I.C.I. Ltd. Phenyl mercuric nitrate was purchased from BDH Ltd. and glutaraldehyde from Sigma Ltd. The phenolic preparation was Hycolin (Pearson Ltd., Clough Road, Hull) which contains I6 per cent $\mathrm{v} / \mathrm{v}$ of a mixture of chloroxylenol, chlorocresol, chlorophene, sodium O-phenylphenate and sodium pentachlorophenate in a basis of anionic emulsifer and alcohol. The sixth antibacterial agent was the proprietary antiseptic Resiguard (Nicholas Laboratories Ltd.), which contains picloxydine digluconate ( I per cent $\mathrm{v} / \mathrm{v}$ ), octyl phenoxy-polyethoxyethanol ( I I 0 per cent $\mathrm{w} / \mathrm{v}$ ) and benzalkonium chloride ( 12 per cent $\mathrm{w} / \mathrm{v}$ ).

\section{MIC Determinations}

Each isolate was grown for 18 hours at $37^{\circ}$ in nutrient broth (Oxoid Nutrient Broth No. 2), and volumes $(5 \mu \mathrm{l})$ of a $\mathrm{IO}^{-4}$ dilution of the cultures, each containing approximately $1 \mathrm{I}^{3}$ viable cells, were dropped onto the surface of nutrient agar plates containing various concentrations of the antibacterials. The lowest concentration of the agent preventing colony formation after overnight incubation at $37^{\circ}$ was taken as the MIC for that strain. The tests were performed in duplicate and with each batch of strains tested $E$. coli $\mathrm{I} 04 \mathrm{I} 8$ and $\mathrm{Pr}$. mirabilis $6 \mathrm{I}$ were included as control reference organisms with known MICs.

\section{Antibiotic Sensitivity}

The antibiotic sensitivity patterns were determined on DST agar (Oxoid Ltd.) using $\mathrm{U}_{3}$ Multodiscs (Oxoid Ltd.), which are impregnated with the following antibiotics:-

gentamicin (Io $\mu \mathrm{g}$ ), colistin (Io $\mu \mathrm{g}$ ), nitrofurantoin (200 $\mu \mathrm{g}$ ), sulphafurazole (500 $\mu \mathrm{g})$, kanamycin $(30 \mu \mathrm{g})$, ampicillin $(25 \mu \mathrm{g})$, sulphamethoxazole/trimethoprim $(25 \mu \mathrm{g})$ and tetracycline $(50 \mu \mathrm{g})$.

\section{Results}

In a I2-month period a total of 57 isolates of Gram-negative bacilli were examined. The most common genera were Proteus, Providencia and Pseudomonas 
(Table I). The results of the sensitivities of the organisms to the six antiseptics and disinfectants are shown in Figs. I-6. The bacteria were grouped on the basis of the

\section{TABLE I}

Gram-negative bacterial species isolated from urinary tract infections over a period of 12 months

\begin{tabular}{lc}
\hline \multicolumn{1}{c}{ Species } & Number of Isolates \\
\hline E. coli & 5 \\
Proteus sp. & $\mathrm{I} 4$ \\
Providencia stuartii & $\mathrm{I} 6$ \\
Pseudomonas aeruginosa & $\mathrm{I} 4$ \\
Klebsiella pneumoniae & 5 \\
Citrobacter sp. & $\mathrm{I}$ \\
Acinetobacter sp. & 2 \\
& - \\
Total & 57 \\
\hline
\end{tabular}

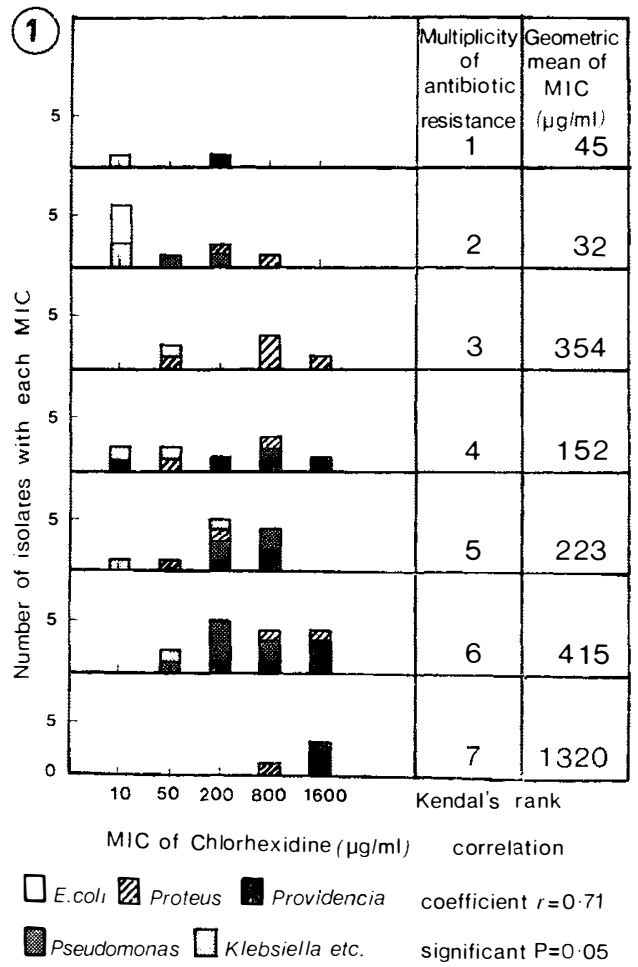

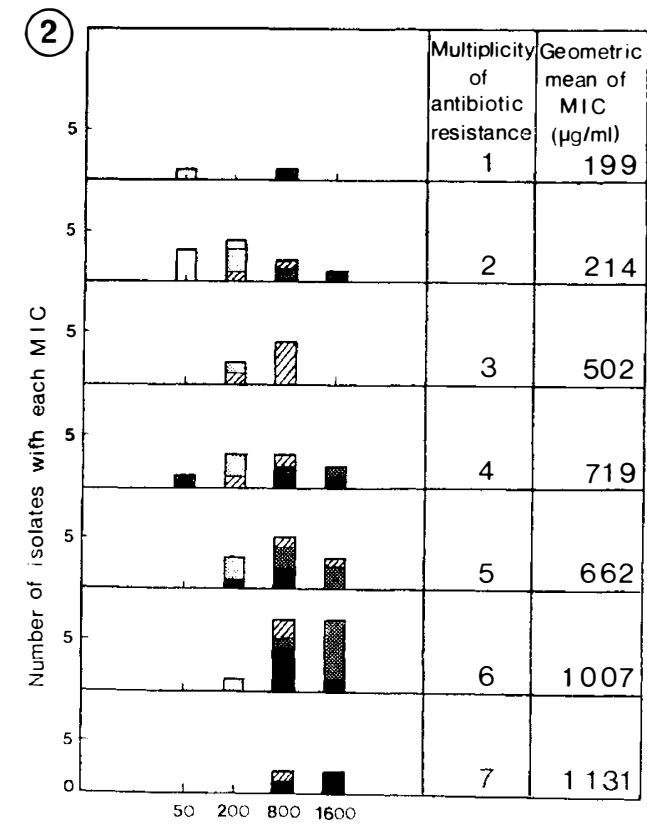

MIC of Cetrimide $(\mu \mathrm{g} / \mathrm{ml})$

Kendal's rank correlation coefficient $r=0.905$ sig. $P=0.01$

FIG. I

The sensitivity of the isolates to chlorhexidine.

FIG. 2

The sensitivity of the isolates to cetrimide. 


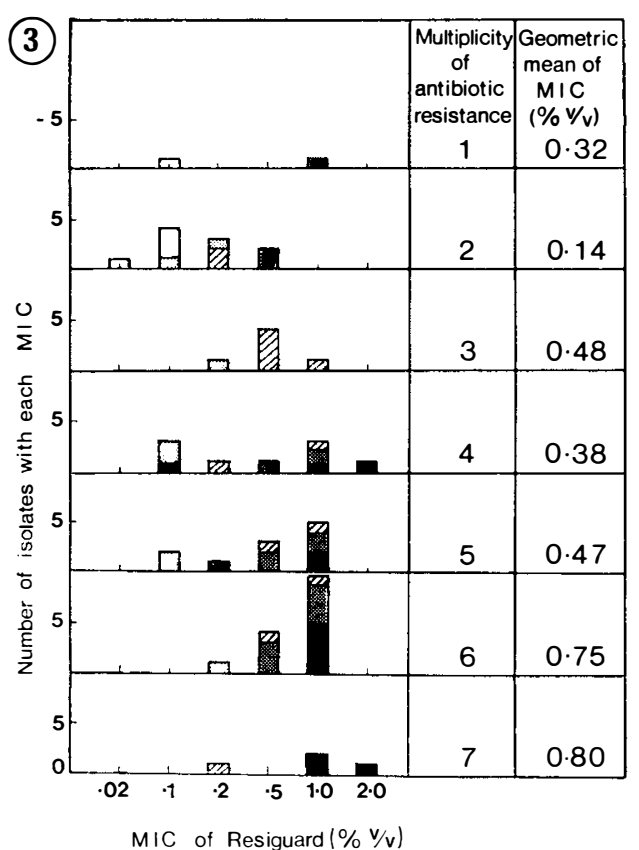

Kendal's rank correlation coefficient $r=0.71$ sig. $P=0.05$

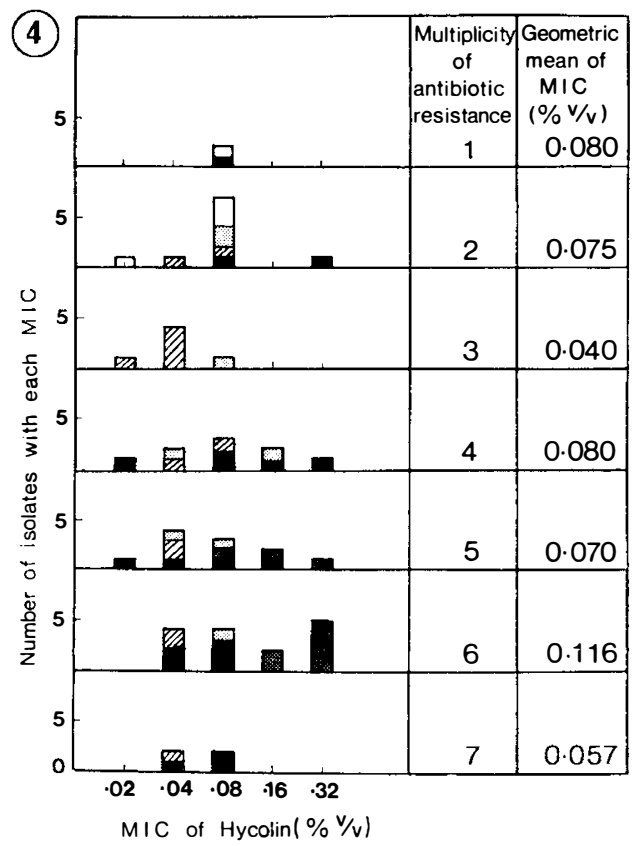

Kendal's rank correlation coefficient $r=-0.098$ not sig.

FIG. 3

The sensitivity of the isolates to Resiguard.

FIG. 4

The sensitivity of the isolates to Hycolin.

multiplicity of their antibiotic resistance and the histograms represent the numbers of isolates having each MIC. The MICs recorded for the control sensitive strain E. coli I04I8 are shown in Table II.

\section{TABLE II}

The minimum inhibitory concentrations of the six agents for E. Coli NCTC Io4I8

\begin{tabular}{lc}
\hline \multicolumn{1}{c}{ Agent } & MIC of E.Coli I04I8 \\
\hline Chlorhexidine & $4 \mu \mathrm{g} / \mathrm{ml}$ \\
Cetrimide & $50 \mu \mathrm{g} / \mathrm{ml}$ \\
Resiguard & $\leqq 0.02 \% \mathrm{v} / \mathrm{v}$ concentrate \\
Glutaraldehyde & $0.08 \% \mathrm{v} / \mathrm{v}$ \\
Hycolin & $0.08 \% \mathrm{v} / \mathrm{v}$ concentrate \\
Phenyl mercuric nitrate & $0.2 \mu \mathrm{g} / \mathrm{ml}$ \\
\hline
\end{tabular}

The geometric means of the MICs of each agent for each group of isolates was calculated. The groups were then ranked on the basis of their multiplicity of 


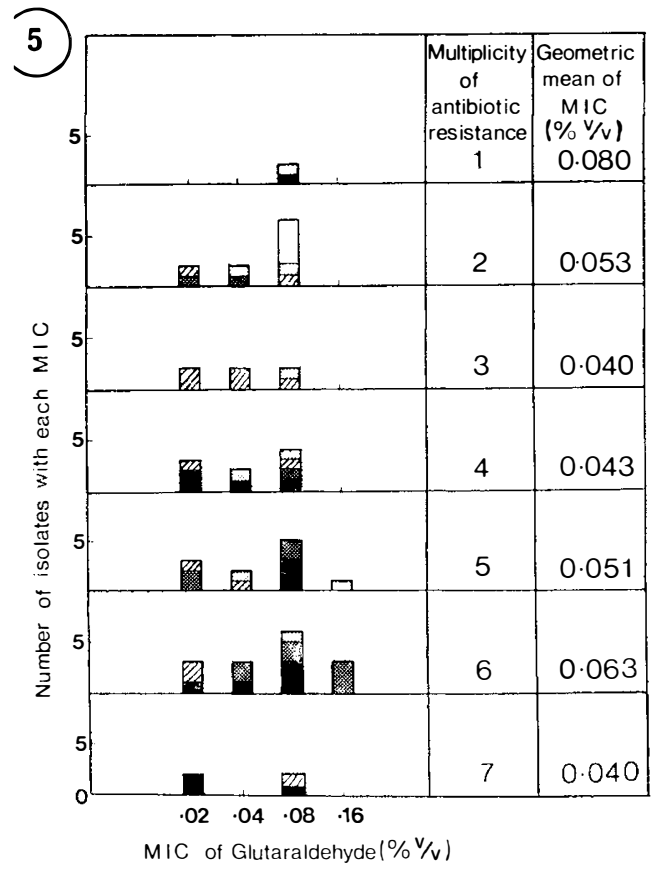

Kendal's rank correlation coefficient $r=-0.293$ not sig

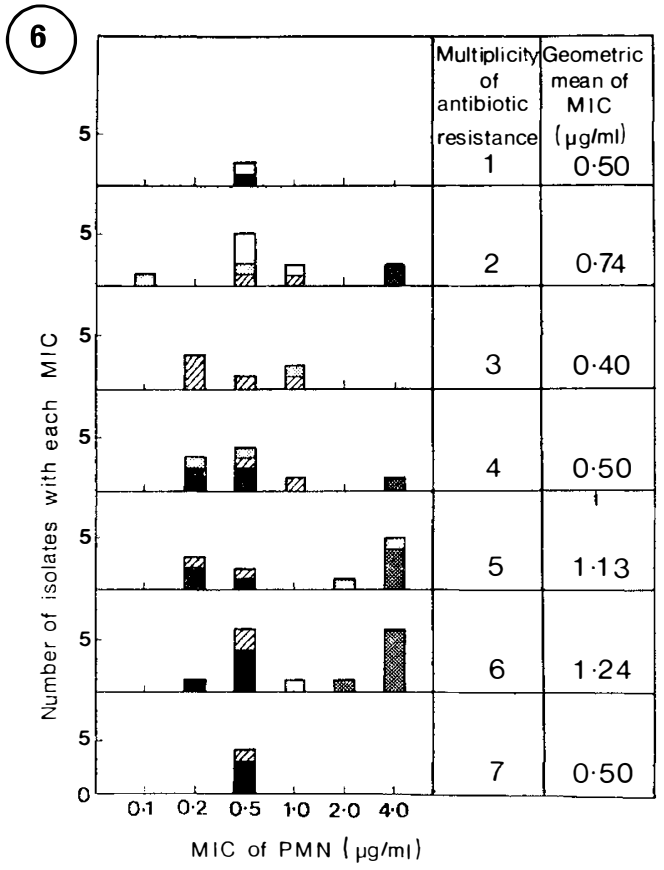

Kendal's rank correlation coefficient $r=0.244$ not sig.

FIG. 5

The sensitivity of the isolates to glutaraldehyde.

FIG. 6

The sensitivity to phenyl mercuric nitrate.

antibiotic resistance and on their mean MICs for each agent. Any correlations between these two parameters for the six agents were then determined using Kendal's rank correlation coefficient.

In designating strains as sensitive or resistant to antiseptics or disinfectants it is difficult to know what criteria to apply. The one normally used for antibiotics i.e. organisms are considered resistant if they are able to multiply in the maximum concentrations of the drug attainable at the site of the infection, is obviously not applicable to antiseptics and disinfectants.

In a previous report (Stickler \& Thomas, 1980), it was decided to designate an organism as resistant if its MIC value was greater than the concentration of the agent normally recommended for routine use. When this criterion is applied to the isolates from the spinal injury unit (Table III), it appears that all isolates are sensitive to glutaraldehyde, the phenolic agent and phenyl mercuric nitrate. A substantial proportion of the Proteus, Providencia and Pseudomonas however, were recorded as resistant to the cationic agents chlorhexidine, cetrimide and Resiguard.

The earlier paper compared the chlorhexidine resistance of isolates from general practice and ante-natal clinics with those originating from hospital inpatients. In Table IV we present an analysis of the MICs of the non-hospital isolates and those from the spinal injury unit for all 6 agents. 


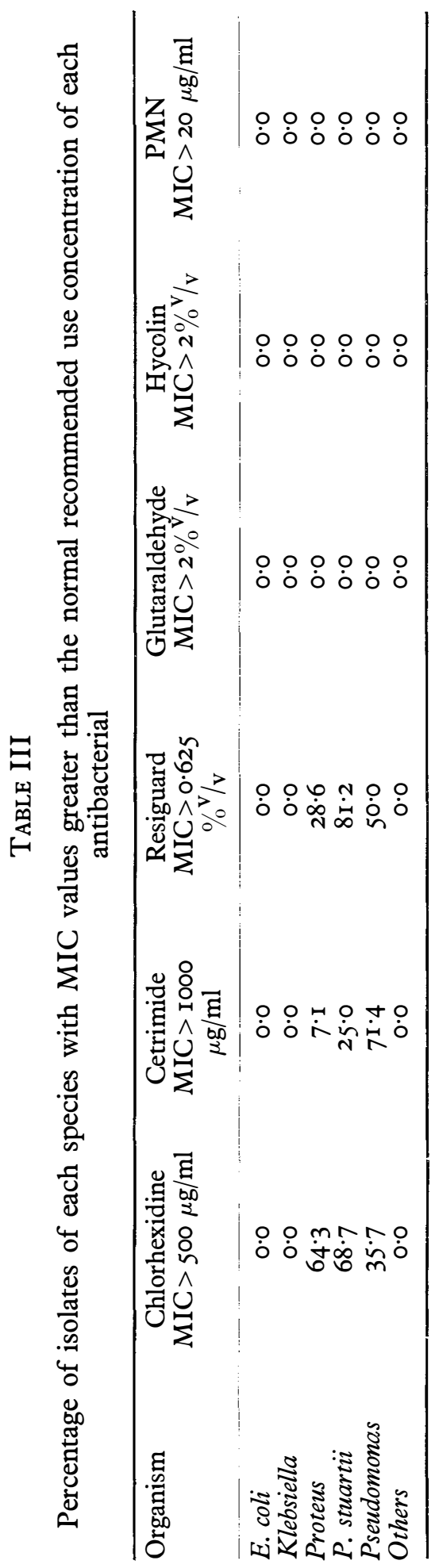




\section{TABLE IV}

A comparison of the incidence of antiseptic resistance in isolates from general practice and ante-natal clinics against those from the spinal injury unit

\begin{tabular}{|c|c|c|}
\hline \multirow[t]{2}{*}{ Antibacterial Agent } & \multicolumn{2}{|c|}{$\begin{array}{l}\% \text { of isolates resistant to each antiseptic: } \\
\text { i.e. having MIC > the normal recommended } \\
\text { use concentration }\end{array}$} \\
\hline & $\begin{array}{l}\text { Isolates from general } \\
\text { practice \& ante-natal } \\
\text { clinics (total of 200) }\end{array}$ & $\begin{array}{l}\text { Isolates from the } \\
\text { spinal injury unit } \\
\text { (total of 57) }\end{array}$ \\
\hline Chlorhexidine & $2 \cdot 5$ & $44^{\circ} \circ$ \\
\hline Cetrimide & 0.5 & $26 \cdot 4$ \\
\hline Resiguard & $4 \cdot 5$ & $42 \cdot 2$ \\
\hline Glutaraldehyde & $0 \cdot 0$ & $0 \cdot 0$ \\
\hline Hycolin & 0.0 & 0.0 \\
\hline PMN & 0.0 & 0.0 \\
\hline
\end{tabular}

\section{Discussion}

The organisms isolated during this survey were typical of the Gram-negative species causing urinary tract infections in spinal injury units (Milner, 1963). In our case the predominant genera were Proteus, Providencia and Pseudomonas, bacteria notorious for their multi-drug resistance (Garrod et al., 1973). These organisms were also the least sensitive to the cationic antiseptics chlorhexidine, cetrimide and Resiguard (Figs. I-3), many of them having MICs for these agents greater than the normally used concentrations (Table III). Analysis of the data presented in Figs. I- 6 revealed significant positive correlations between multiplicity of drug resistance and MIC of the antiseptics chlorhexidine, cetrimide and Resiguard. No such correlations were established with glutaraldehyde, Hycolin or phenyl mercuric nitrate.

The MIC determinations are of course in vitro tests which yield interesting information on the relative sensitivities of bacteria to antibacterial agents in the laboratory. We cannot be certain that the MIC value for an antiseptic will represent the concentration that will be effective in a clinical situation. However, the observation that urine-grown organsims with MICs of chlorhexidine $\geqq 800$ $\mu \mathrm{g} / \mathrm{ml}$ survived well when challenged with the recommended level of this antiseptic provided some indication of the clinical relevance of our criterion of resistance (Thomas et al., 1978).

Stickler \& Thomas (1980) concluded that resistance to antiseptics and disinfectants is not a widespread phenomenon in bacteria responsible for urinary infections. Examination of 200 Gram-negative isolates from urinary tract infections in patients from general practice or attending ante-natal clinics (Table IV) indicates that none of the strains were resistant to glutaraldehyde, Hycolin or phenyl mercuric nitrate and only small percentages were resistant to chlorhexidine $(2.5)$, cetrimide $(0.5)$ and Resiguard $(4.5)$.

Attempts to control urinary infections in spinal injury units involve the considerable use of antibiotics and antiseptics. It is inevitable, therefore, that under the influence of this intense selective pressure organisms resistant to these agents will emerge as the predominant flora. Unfortunately, it seems that the 
extensive use of cationic antiseptics, such as chlorhexidine, for washing the external genitalia before insertion of the catheter, for inclusion in the cream used to facilitate the passage of the catheter through the urethra (Gillespie et al., I967) and even for instillation into the urine drainage bags (Blandy, 1970), all manoeuvres designed to prevent infection, could well select Proteus, Providencia and Pseudomonas, the bacteria likely to be antibiotic resistant.

Guttmann (1973), advocated the use of phenoxyethanol as an antiseptic in the management of bladder catheterisation when Pseudomonas aeruginosa was prevalent in a unit. The effectiveness of this agent against $P$. aeruginosa has been known for some time and it appears to be more active against this species than against $E$. coli and even Gram-positive organisms (Berry, 1944; Gough, Berry and Still, 1944). Thomas et al., (1978) also found that it was bactericidal against urine grown cultures of $P$. aeruginosa, Proteus mirabilis and Providencia stuartii known to be resistant to be cationic antiseptics. It was unfortunate that phenoxyethanol was not included in the list of antiseptics used in this study.

A prophylactic policy employing an antiseptic to which multi-drug resistant strains are especially sensitive, i.e. one where the MICs for bacteria are negatively correlated with multiplicity of drug resistance, might be particularly effective and lead to the selection of organisms which were amenable to chemotherapy. In future work we hope to compare the antibiotic and phenoxyethanol sensitivity of bacteria causing urinary infections in the spinal injured patients to establish if phenoxyethanol could be used in such a policy.

\section{RÉSUMÉ}

Nous avons assemblé 57 espèces bactériennes Gram-négatives isolées de l'urine infectée de malades qui avaient souffert une blessure au cordon médullaire. Ensuite nous avons mis ces isolés à l'épreuve pour leur sensitivité à chlorhexidine, cetrimide, glutaraldehyde, phenyl mercuric nitrate (PMN), un désinfectant phénolique (Hycolin) et à un antiseptique de propriété qui contenait une mixture de picloxydine, d'octylphenoxypolyethoxyethanol et de benzalkonium chloride (Resiguard). Aucun des isolés n'était résistant à glutaraldehyde, à Hycolin ni à $\mathrm{PMN}$ mais de pourcentages considérables d'entre eux étaient résistants à chlorhexidine $(44 \%)$ cetrimide $(26 \%)$ et à Resiguard $(42 \%)$. Les organismes résistants étaient membres des genres Proteus, Providencia et Pseudomonas et ils étaient aussi résistants en général à 5,6 ou 7 antibiotiques. Des correlations significatives ont été observées entre la multiplicité de résistance aux antibiotiques et la concentration minimum inhibituese des trois antiseptiques cationiques. Il est proposé qu'un système antiseptique pour le contrôle de la vessie de ceux qui ont reçu une blessure au cordon médullaire, qui fait fond sur l'emploi considérable d'agents cationiques, pourrait aboutir à la selection d'une flore des espèces, bien connues d'être résistants aux produits pharmaceutiques.

\section{ZUSAMMENFASSUNG}

Eine Sammlung von 57 Isolaten von Gram-negativ bakteriellen Spezimen, entnommen von Urintract-Infektionen bei Reuckenmarkverletzten Patienten, wurden auf ihre Sensitaet zu Chlorhexidine, Cetrimide, Glutaraldehyde, Phenyl mercuric Nitrate (PMN) ein Phenolic Desinfektant (Hycolin) und eine Mischung von Picloxydine Octylphenoxypolyethoxyethanol und Benzalkonium Chloride (Resiguard). Keine von diesen Isolaten war Resistenz zu Glutaraldehyde, Hycolin oder PMN, aber ein wesentlicher Prozentsatz, von diesen war Resistenz zu Chlorhexidine (44\%), Cetrimide $(26 \%)$ und Resiguard $(42 \%)$. Die widerstands Organismen waren Mitglieder der Gemeinschaft Proteus, Providencia und Pseudomonas welche auch im allgemeinen Widerstand zu 5, 6 oder 7 verschiedenen Antibiotikas zeigten. Eine Bedeutende Wechselbeziehung wurde beobachtet zwischen einem vermerten antibiotischen Widerstand und dem minimum hemmender Saettigung der drei kationischen Antiseptika. Fuer die Blasenkintrolle der Rueckenmarkverletzten Patienten ist eine 
antiseptische Methode vorgeschlagen worden welche sich auf den ausgedehnten Gebrauch der kationischen Kraft verlaesst und moeglicherweise zur Auswahl einer Flora von bereuchtigten Drogen-widerstaendigen Gattung feuhren koennte.

\section{REFERENCES}

BerRy, H. (1944). Antibacterial values of ethylene glycol mono-phenyl ether. Lancet, 2, I75-I 76.

Blandy, J. P. (1970). Catheterization. British fournal of Hospital Medicine, 4, I79-182.

CowAN, S. T. \& STEEL, K. J. (1974). Manual for the Identification of Medical Bacteria. 2nd Edition. London: Cambridge University Press.

Davies, G. E., Francis, J., Martin, A. R., Rose, F. L. \& Swain, G. (I954). I : 6-di-4' chlorophenyldiguanidohexane (Hibitane): laboratory investigation of a new antibacterial agent of high potency. British fournal of Pharmacology \& Chemotherapy, 9, I92-196.

Garrod, L. P., Lambert, H. P. \& O’Grady, F. (1973). Antibiotic and Chemotherapy. 4th Edition. Edinburgh: Churchill Livingstone.

Gillespie, W. A., Lennon, G. G., Linton, K. B. \& Phippen, G. A. (I967). Prevention of urinary infection by means of closed drainage into a sterile plastic bag. British Medical fournal, 3, 90-92.

Gough, J., Berry, H. \& Still, B. M. (1944). Phenoxetol in the treatment of Pyocyanea infections. Lancet, 2, I76-I 78.

Guttmann, L. (1973). Spinal Cord Injuries. Comprehensive Management \& Research. Oxford: Blackwells.

MILNER, P. F. (I963). The differentiation of Enterobacteriaceae infecting the urinary tract: a study in male paraplegics. Fournal of Clinical Pathology, 16, 39-45.

O'FlynN, J. D. \& StiCKLER, D. J. (I972). Disinfectants and Gram-negative bacteria. Lancet, $\mathbf{I}, 489-490$.

Stickler, D. J. (I974). Chlorhexidine resistance in Proteus mirabilis. Fournal of Clinical Pathology, 27, 284-287.

Stickler, D. J. \& Thomas, B. (1976). Sensitivity of Providence to antiseptics and disinfectants. Fournal of Clinical Pathology, 29, 81 5-823.

STICKLER, D. J. \& ThomAs, B. (I980). Antiseptic and antibiotic resistance in Gramnegative bacteria causing urinary tract infection. Fournal of Clinical Pathology, 33, 288-296.

Stickler, D. J., Wilmot, C. B. \& O'FlynN, J. D. (I97I). The mode of development of urinary infection in intermittently catheterized male paraplegics. Paraplegia, 8, 243-252.

Thomas, B., Sykes, L. \& STICkLer, D. J. (I978). Sensitivity of urine grown cells of Providencia stuartii to antiseptics. Fournal of Clinical Pathology, 3I, 929-932. 